2017-01-01

Comparing the acute sensitivity of growth and photosynthetic endpoints in three Lemna species exposed to four herbicides

Park, J

http://hdl.handle.net/10026.1/6695

10.1016/j.envpol.2016.10.064

Environmental Pollution

All content in PEARL is protected by copyright law. Author manuscripts are made available in accordance with publisher policies. Please cite only the published version using the details provided on the item record or document. In the absence of an open licence (e.g. Creative Commons), permissions for further reuse of content should be sought from the publisher or author. 


\title{
Comparing the acute sensitivity of growth and photosynthetic endpoints in three Lemna species exposed to four herbicides ${ }^{\text {th }}$
}

\author{
Jihae Park a, b, Murray T. Brown ${ }^{\text {c}}$, Stephen Depuydt ${ }^{\text {b }}$, Jang K. Kim ${ }^{\text {d }}$, Dam-Soo Won ${ }^{\text {e, }}$ \\ Taejun Han d, * \\ a Division of Life Science, Incheon National University, 119, Academy-ro, Yeonsu-gu, Incheon 22012, Republic of Korea \\ b Lab of Plant Growth Analysis, Ghent University Global Campus, Songomunhwa-ro, 119 Yeonsu-gu, Incheon 21985, Republic of Korea \\ ' School of Marine Science \& Engineering, Plymouth University, Plymouth, Devon, PL4 8AA, United Kingdom \\ ${ }^{\mathrm{d}}$ Department of Marine Science, Incheon National University, 119, Academy-ro, Yeonsu-gu, Incheon 22012, Republic of Korea \\ e Water Supply Operations \& Maintenance Department, Korea Water Resources Corporation, 200 Sintanjin-ro, Daedeok-gu, Daejun 61949, Republic of \\ Korea
}

\section{A R T I C L E I N F O}

\section{Article history:}

Received 27 July 2016

Received in revised form

18 October 2016

Accepted 22 October 2016

Available online xxx

\section{Keywords:}

Herbicides

Lemna

Frond area

Root length

Chlorophyll $a$ fluorescence

Toxicity

\begin{abstract}
A B S T R A C T
An ecological impact assessment of four herbicides (atrazine, diuron, paraquat and simazine) was assessed using the aquatic floating vascular plants, Lemna gibba, Lemna minor and Lemna paucicostata as test organisms. The sensitivity of several ecologically relevant parameters (increase in frond area, root length after regrowth, maximum and effective quantum yield of PSII and maximum electron transport rate $\left(\mathrm{ETR}_{\max }\right)$, were compared after a $72 \mathrm{~h}$ exposure to herbicides. The present test methods require relatively small sample volume $(3 \mathrm{~mL})$, shorter exposure times $(72 \mathrm{~h})$, simple and quick analytical procedures as compared with standard Lemna assays. Sensitivity ranking of endpoints, based on $\mathrm{EC}_{50}$ values, differed depending on the herbicide. The most toxic herbicides were diuron and paraquat and the most sensitive endpoints were root length $\left(6.0-12.3 \mu \mathrm{g} \mathrm{L}^{-1}\right)$ and $\mathrm{ETR}_{\max }\left(4.7-10.3 \mu \mathrm{g} \mathrm{L}^{-1}\right)$ for paraquat and effective quantum yield (6.8-10.4 $\mu \mathrm{g} \mathrm{L}^{-1}$ ) for diuron. Growth and chlorophyll $a$ fluorescence parameters in all three Lemna species were sensitive enough to detect toxic levels of diuron and paraquat in water samples in excess of allowable concentrations set by international standards. $\mathrm{CV}$ values of all $\mathrm{EC}_{50} \mathrm{~S}$ obtained from the Lemna tests were in the range of $2.8-24.33 \%$, indicating a high level of repeatability comparable to the desirable level of $<30 \%$ for adoption of toxicity test methods as international standards. Our new Lemna methods may provide useful information for the assessment of toxicity risk of residual herbicides in aquatic ecosystems.
\end{abstract}

๑ 2016 Elsevier Ltd. All rights reserved.

\section{Introduction}

Aquatic environments are subjected to contamination by the inundation of a variety of toxicants derived from anthropogenic activities. Herbicides are one of the most widely used groups of organic chemicals, with application particularly prevalent in, agriculture, horticulture and, amenity green spaces such as parks, golf courses and sports fields (Fatima et al., 2007). It has been reported that $99.7 \%$ of the applied load is dispersed as residues which enter aquatic environments through run-off and leaching (Kloeppel et al.,

\footnotetext{
This paper has been recommended for acceptance by Klaus Kummerer.

* Corresponding author.

E-mail address: hanalgae@hanmail.net (T. Han).
}

1997; Prado et al., 2009) and can lead to both negative direct and indirect effects on aquatic biota that are detectable at multiple levels of biological organization, from the molecular to the ecosystem. There is now increasing public awareness of the potential risks posed by herbicides not just to water quality and nontarget organisms but also to human health (Hernández et al., 2013). Therefore, effective monitoring and management strategies need to be developed so that the integrity of aquatic ecosystems can be maintained. For this to happen, policies must be underpinned by meticulous quantitative data on both the detection of herbicides in aquatic ecosystem and their risks to aquatic life.

Conventionally, sophisticated analytical methods using HPLC and Mass Spectrometry have been used for measuring herbicide residues. Chemical analysis as a methodology for herbicide detection is highly specific and sensitive but has several drawbacks 
including the complex procedures for sample preparation, the need for expensive chemicals and equipment, and interference from secondary pollutants during analysis (Park et al., 2012). Moreover, this purely chemical approach does not provide ecologically significant information on temporal changes in exposure or the interactive effects of pollutants (Kumar and Han, 2010). To compensate for these limitations biological assays have been developed and employed to assess pollutant-induced ecological risks. Especially, aquatic bioassay is an important means of assessing the quality of water containing mixtures and unknown contaminants and of providing the safety standards for water management in an ecological context that cannot be expected from the conventional chemical analysis-driven management since the latter method relies on the measurements of single and standardized chemicals. The choice of a model organism for toxicity testing is dependent on sensitivity to specific pollutants, with many species of zooplankton, phytoplankton and macroscopic organisms being used. Amongst them, aquatic macrophytes belonging to the class Lemnaceae are attractive experimental model organisms for a number of reasons including their simple structure, small stature, degree of homogeneity, ease of culture and high growth rate (a doubling time of 2-4 d) (Hillman, 1961; Wang and Williams, 1990; Christen and Theuer, 1996; Kumar and Han, 2010; Lahive et al., 2011). Moreover, these plants have important ecological functions and are widely distributed, and are known to be highly sensitive to organic and inorganic substances, including herbicides, pharmaceuticals and metals (Lahive et al., 2011; Scherr et al., 2008; Wang, 1990). Macrophytes are a major group of primary producers at the base of trophic hierarchies in aquatic ecosystems and have prime importance since any negative impacts on them can have serious consequences higher up food chains, leading to alteration in the diversity and functionality of whole aquatic ecosystems. For these reasons, laboratory toxicity testing with Lemna spp. (duckweed) is one of the choice methodologies for assessing impacts on freshwater systems (Moody and Miller, 2005).

\subsection{Lemna spp, particularly Lemna gibba and L. minor are being} used for decades in

prospective risk assessment of pesticides worldwide (USA, Europe). In Europe, for example, Lemna spp. were, until 2013, the only standard species of aquatic macrophyte species mandatory for regulatory driven risk assessment of each and every herbicides and plant growth regulators in the process of registration (Giddings et al., 2012).

The ultimate goal of bioassay tests is to provide representative and incorporative criteria of exposure conditions, thereby improving risk assessment and management of water quality. In this respect, multiple, rather than single, endpoint assays may have a greater potential for more comprehensive risk assessment of toxicants. Such an approach makes it possible to gain important insights into the mechanisms of toxicity and obtain information on the relative sensitivity of the measured endpoints to toxicant concentration and/or exposure duration thereby identifying specific endpoints which can effectively detect disturbances caused by particular phytotoxicants (Nestler et al., 2012). Many endpoints have been applied in Lemna, including frond number, plant number, root number, dry or fresh biomass, frond diameter or area, root length, carbon uptake, chlorophyll content, etc. (see reviews by Wang, 1990). Recently, Gopalapillai et al. (2014) reported root length of Lemna minor as to be the optimal endpoint for biomonitoring of mining effluents. The authors considered average root length $(\mathrm{RL})$ the ideal endpoint for three reasons: accuracy (i.e., toxicological sensitivity to the contaminant), precision (i.e., lowest variance), and ecological relevance (metal mining effluents)
(Gopalapillai et al., 2014). A well-defined toxicant concentrationdependent inhibition of root re-growth has also recently been shown with the root re-growth test using three Lemna species (Park et al., 2013). Several operational benefits of this method over that of more conventional techniques (ISO20079) were highlighted by the authors, including: completion of the test after $48 \mathrm{~h}$, a test solution of only $3.0 \mathrm{~mL}$ and the use of non-axenic plant material.

The technique of pulse amplitude modulated (PAM) chlorophyll $a$ (Chl $a$ ) fluorescence, which is based on measurements of the fluorescence from Chl $a$ in photosystem II (PS II) reaction centers, is considered to be a rapid and sensitive tool for evaluating toxicity in algae and higher plants (Juneau and Popovic, 1999; Ralph and Gademann, 2005; Schreiber et al., 2007). The approach has already been successfully employed with Lemna spp. To assess the toxicity of, for example, the phenylurea herbicide linuron in L. minor (Hulsen et al., 2002), the wood preservative creotose, sewage treatment plant effluent and copper oxide nanoparticles in L. gibba (Marwood et al., 2001; Juneau et al., 2003 and Perreault et al., 2010) and four herbicides in Lemna paucicostata (Kumar and Han, 2010).

The four herbicides tested in this study are the most frequently detected herbicides in water bodies. The effects of atrazine, diuron, paraquat and simazine on three species of Lemna (L. gibba, L. minor and $L$. paucicostata) using various endpoints have been investigated in this study. The four herbicides were selected for their common use to control weeds in agricultural activities, and are discharged into aquatic ecosystems through surface runoff, thus potentially causing toxicity to non-target species. While they effectively control targeted weedy species, it is also important to establish their effects on non-targeted species, which are less well known. Specifically, data obtained from root re-growth and Chl $a$ fluorescence measurements are compared with those based on a traditional endpoint of frond area. The accuracy and precisions (sensu Gopalapillai et al., 2014) of the three endpoints are evaluated.

\section{Materials and method}

\subsection{Sample \& culture conditions}

Lemna gibba (CPCC 310), L. minor (CPCC 490) and L. paucicostata were used as research materials in the present study. L. paucicostata was collected from a shallow pond in Songjung-dong, Kwangsangu, Kwangju, Korea (35.09 N, 125.54 E), and the other two species were obtained from Canadian Phycological Culture Center. Experimental material was cultured in glass tanks $(20 \mathrm{~cm} \times 30 \mathrm{~cm} \times 15 \mathrm{~cm})$ containing $1.5 \mathrm{~L}$ of Steinberg medium (Steinberg, 1946), adjusted to a pH of $6.9 \pm 0.1$ with $1 \mathrm{M} \mathrm{NaOH}$ and $1 \mathrm{M} \mathrm{HCl}$, at $25 \pm 1{ }^{\circ} \mathrm{C}$ and an irradiance of $30-40 \mu \mathrm{mol}$ photons $\mathrm{m}^{-2}$ $\mathrm{s}^{-1}$, provided by cool white fluorescent lamps (FL 20 SS/18D, Philips Co., Thailand). The growth medium was replaced every week.

\subsection{Toxicity tests}

To compare the relative sensitivities of the three Lemna spp. to four herbicides (atrazine, diuron, paraquat and simazine), fronds of each species, consisting of two green leaves of similar size, were selected as test material.

Tests were carried out in a controlled environment chamber at $25 \pm 1{ }^{\circ} \mathrm{C}$ and continuous light of $100 \pm 10 \mu \mathrm{mol}$ photons $\mathrm{m}^{-2} \mathrm{~s}^{-1}$. Test vessels were 24 -well plastic plates $(85.4 \mathrm{~mm} \times 127.6 \mathrm{~mm}$; well dimension $15.6 \mathrm{~mm}$ diameter, SPL, Seoul Korea) with $3.0 \mathrm{ml}$ of test solution added to each well. All herbicide stock solutions were prepared from original stock solution (Table 1) in either DMSO (for atrazine, diuron and simazine) or distilled water (for paraquat) and then diluted in a 50\% dilution series (five or more concentrations 
Table 1

Final concentration range and mode of action used for testing toxicity of herbicides with three Lemna species.

\begin{tabular}{|c|c|c|c|c|c|}
\hline \multirow[t]{2}{*}{ Herbicides (CAS No.) } & \multirow[t]{2}{*}{ Physiological site } & \multirow[t]{2}{*}{ Molecular targets } & \multicolumn{3}{|c|}{ Concentrations $\left(\mu \mathrm{g} \mathrm{L}^{-1}\right)$} \\
\hline & & & Lemna gibba & Lemna minor & Lemna paucicostata \\
\hline Atrazine (1912-24-9) & Photosynthesis & Qb site of D1 protein & $31.25-500.0$ & $31.25-500.0$ & $31.25-500.0$ \\
\hline Diuron (330-54-1) & Photosynthesis & Qb site of $\mathrm{D} 1$ protein & $3.125-100.0$ & $3.125-100.0$ & $6.25-100.0$ \\
\hline Paraquat (1910-42-5) & Photosynthesis & Electron acception from PSI & $6.25-100.0$ & $6.25-100.0$ & $6.25-100.0$ \\
\hline Simazine (122-34-9) & Photosynthesis & Qb site of $\mathrm{D} 1$ protein & $31.25-500.0$ & $31.25-500.0$ & $31.25-500.0$ \\
\hline
\end{tabular}

plus solvent and negative controls; triplicate replication) using the Steinberg medium.

In each of three replicate plates, 24 plants each comprising two fronds were exposed to one of 6 concentrations of herbicide, with 4 plants per concentration.

\subsubsection{Frond area and root re-growth}

Prior to exposure to test solutions roots were excised from fronds using scissors as described in detail elsewhere (Park et al., 2013). Fronds were then added to wells under the same conditions as described in Park et al. (2013). Following $72 \mathrm{~h}$ of exposure to different concentrations of herbicides, plants were harvested to determine changes in surface area using an image analyzer (MV200, Samsung, Seoul, Korea). The relative growth rates $\left(\mathrm{RGR}_{\text {area }}\right)$ were determined according to the formula:

$\operatorname{RGR}_{\text {area }}\left(\% \mathrm{~d}^{-1}\right)=\frac{\ln A_{f}-\ln A_{i}}{t_{f}} \times 100$

where $A_{i}=$ initial frond area, $A_{f}=$ final frond area and $t_{f}=$ the test duration.

Lengths of longest roots (each frond generally has $1-2$ roots) were measured with the same instrument.

\subsubsection{Chlorophyll (Chl) a fluorescence}

Chl $a$ fluorescence was measured simultaneously in all frond samples using a pulse amplitude modulated imaging fluorometer (I-PAM, Walz, Effeltrich, Germany). After exposure, samples were dark adapted for 15 min to obtain the equilibrium of the PSII oxidoreduction state (Ralph, 1997). Maximum quantum yield of PSII in the dark-adapted state $\left(F_{v} / F_{m}\right)$, derived from $\left(F_{m}-F_{o}\right) / F_{m}$, where $F_{m}$ and $F_{o}$ are the maximum and minimum fluorescence of darkadapted fronds, was recorded. This is a very important plant property that indicates how efficient the light reaction is proceeding (Ritchie, 2006). The effective quantum yield of PSII, calculated as $\left(\mathrm{F}_{\mathrm{m}}^{\prime}-\mathrm{F}\right) / \mathrm{F}_{\mathrm{m}}^{\prime}$, where $\mathrm{F}_{\mathrm{m}}^{\prime}$ is the maximum light-adapted fluorescence yield and $\mathrm{F}$ is the lowest fluorescence yield at $\mathrm{F}_{\mathrm{O}}$ in dark-adapted samples, was also measured. The effective quantum yield is an actual quantum yield at a point in time and this is generally much lower than the optimal quantum yield (Ritchie, 2006).

Rapid light curves (RLC) were produced using $10 \mathrm{~s}$ pulses of actinic light increased stepwise from 0 to $1517 \mu \mathrm{mol}$ photons $\mathrm{m}^{-2} \mathrm{~s}^{-1}$. The levels of the measuring and saturating light were $<0.4 \mu \mathrm{mol}$ photons $\mathrm{m}^{-2} \mathrm{~s}^{-1}$ and $>6000 \mu \mathrm{mol}$ photons $\mathrm{m}^{-2} \mathrm{~s}^{-1}$ for $0.4-0.8 \mathrm{~s}$, respectively. Maximum electron transport rates $\left(\mathrm{ETR}_{\max }\right)$ were derived from the RLC data using the following equation, with the aid of the program Grapher 3 (Golden Software Inc., USA):

$\mathrm{ETR}=0.5 \times \mathrm{PAR} \times$ Yield $\times \mathrm{AF}$

$\mathrm{AF}$ refers to the absorption of light by Lemna fronds. Green plants generally exhibit a value of approximately 0.84 . However, since this value can vary between species, AF was calculated as the ratio of incident PAR absorbed by the fronds of each Lemna species.
PAR sources were white light fluorescent tubes and PAR levels were measured using a LiCor quantum sensor (LI 1400) before and after covering with fronds.

\subsection{Statistical analysis}

Four herbicides and 5 endpoints were included in the statistical analyses. The results are reported as $\mathrm{EC}_{10} \mathrm{~S}$ and $\mathrm{EC}_{50} \mathrm{~S}$ values with 95\% CI estimated by the linear interpolation method (ToxCalc 5.0, Tidepool Science, CA, USA).

\section{Results}

\subsection{Frond area}

There was a significant decrease in frond area with respect to the type and concentration of herbicide tested $(p<0.05)$. The $\mathrm{EC}_{50} \mathrm{~s}$ of $\mathrm{RGR}_{\text {area }}$ are shown in Tables $2-4$. For this parameter, the rank order of the tested herbicides was: diuron $>$ paraquat $>$ atrazine $>$ simazine for $L$. gibba and $L$. minor and diuron $>$ paraquat $>$ simazine $>$ atrazine for L. paucicostata.

Although diuron was found to be most toxic to all three Lemna species there were species-specific differences in sensitivity as indicated by the $\mathrm{EC}_{50}$ values: L. paucicostata $\left(24.3 \mu \mathrm{g} \mathrm{L}^{-1}\right)>$ L. gibba $\left(29.8 \mu \mathrm{g} \mathrm{L}^{-1}\right)>$ L. minor $\left(34.6 \mu \mathrm{g} \mathrm{L}^{-1}\right)$. The least toxic herbicide for L. gibba and L. minor was simazine $\left(276.1 \mu \mathrm{g} \mathrm{L}^{-1}\right)$ but it was atrazine (342.2 $\left.\mu \mathrm{g} \mathrm{L}^{-1}\right)$ for L. paucicostata.

CV values for frond area were between 2.28 and $14.82 \%$.

\subsection{Root re-growth}

The rank order of herbicide toxicity, derived from $\mathrm{EC}_{50} \mathrm{~S}$ of the inhibition of root regrowth was: paraquat $>$ diuron $>$ atrazine $>$ simazine for $L$. gibba and $L$. minor, and paraquat $>$ diuron $>$ simazine $>$ atrazine for $L$. paucicostata. Paraquat was the most toxic herbicide for all three Lemna species but their sensitivity differed with $\mathrm{EC}_{50}$ values of $7.1 \mu \mathrm{g} \mathrm{L}^{-1}$ for L. gibba, $7.9 \mu \mathrm{g} \mathrm{L}^{-1}$ for L. paucicostata and $10.6 \mu \mathrm{g} \mathrm{L}^{-1}$ for L. minor and (Tables 2-4). The least toxic herbicide was simazine (156.0 and $226.6 \mu \mathrm{g} \mathrm{L}^{-1}$ ) for $L$. gibba and $L$. minor, respectively and atrazine $\left(206.2 \mu \mathrm{g} \mathrm{L}^{-1}\right)$ for $L$. paucicostata as seen in frond area.

Coefficients of variation for root re-growth ranged from 9.86 to $15.06 \%$ for $L$. gibba, $2.4-17.96 \%$ for $L$. minor and $2.50-22.42 \%$ for L. paucicostata.

\subsection{Chlorophyll a fluorescence}

The optimal quantum yield $\left(\mathrm{F}_{\mathrm{v}} / \mathrm{F}_{\mathrm{m}}\right)$ of all Lemna species did not change significantly even on exposure to the highest concentrations of three of the four herbicides tested. The exception was atrazine which caused a $50 \%$ reduction at $351.0 \mu \mathrm{g} \mathrm{L}^{-1}$ for $L$. gibba, $237.7 \mu \mathrm{g} \mathrm{L}^{-1}$ for L. minor and $126.2 \mu \mathrm{g} \mathrm{L}^{-1}$ for L. paucicostata (Tables 2, 3, and 4). Coefficients of variation for all the $\mathrm{EC}_{50}$ values were less than $17.19 \%$. 
Table 2

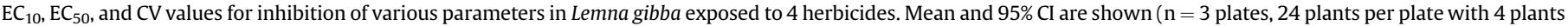
per concentration). (Unit: $\mu \mathrm{g} \cdot \mathrm{L}^{-1}$ ).

\begin{tabular}{|c|c|c|c|c|c|}
\hline \multirow[t]{2}{*}{ End point } & \multirow[t]{2}{*}{ Herbicides } & \multicolumn{4}{|l|}{ Lemna gibba } \\
\hline & & $\mathrm{EC}_{10}(95 \% \mathrm{CI})$ & $\mathrm{CV}(\%)$ & $\mathrm{EC}_{50}(95 \% \mathrm{CI})$ & $\mathrm{CV}(\%)$ \\
\hline \multirow[t]{4}{*}{$\mathrm{RGR}_{\text {area }}$} & Atrazine & $45.3(18.7-63.3)$ & 24.23 & $149.0(119.7-171.7)$ & 8.52 \\
\hline & Diuron & $7.8(3.8-11.9)$ & 28.72 & $29.8(24.0-34.2)$ & 8.72 \\
\hline & Paraquat & $10.5(9.5-11.8)$ & 5.87 & $47.7(41.8-52.1)$ & 6.29 \\
\hline & Simazine & $55.6(17.8-89.9)$ & 39.65 & $276.1(213.4-332.5)$ & 11.30 \\
\hline \multirow[t]{4}{*}{ Root length } & Atrazine & $37.1(13.0-69.3)$ & 40.30 & $111.7(83.6-142.4)$ & 12.18 \\
\hline & Diuron & $4.2(1.7-6.7)$ & 31.26 & $14.8(10.7-18.5)$ & 14.20 \\
\hline & Paraquat & $1.3(1.2-1.5)$ & 6.82 & $7.1(6.0-8.6)$ & 9.86 \\
\hline & Simazine & $58.3(12.3-82.4)$ & 44.23 & $156.0(114.6-200.7)$ & 15.06 \\
\hline \multirow[t]{4}{*}{$\mathrm{F}_{\mathrm{v}} / \mathrm{F}_{\mathrm{m}}$} & Atrazine & $82.0(0-99.6)$ & 17.19 & $352.0(160.4-462.4)$ & 16.17 \\
\hline & Diuron & $10.8(6.7-14.9)$ & 21.52 & $>50.0$ & - \\
\hline & Paraquat & $10.5(8.0-17.2)$ & 26.36 & $>100.0$ & - \\
\hline & Simazine & $157.8(89.7-193.2)$ & 12.57 & $>500.0$ & - \\
\hline \multirow[t]{4}{*}{$\mathrm{F}_{\mathrm{v}}^{\prime} / \mathrm{F}_{\mathrm{m}}^{\prime}$} & Atrazine & $13.6(6.9-55.0)$ & 109.41 & $81.6(48.3-101.8)$ & 17.08 \\
\hline & Diuron & $1.5(1.2-1.9)$ & 11.81 & $9.4(8.6-10.2)$ & 4.19 \\
\hline & Paraquat & $8.0(5.0-11.3)$ & 20.10 & $39.7(36.2-46.8)$ & 7.80 \\
\hline & Simazine & $12.6(11.2-14.1)$ & 5.88 & $79.2(73.8-83.5)$ & 3.09 \\
\hline \multirow[t]{4}{*}{$\mathrm{ETR}_{\max }$} & Atrazine & $11.1(6.0-37.1)$ & 90.45 & $51.5(29.8-73.3)$ & 20.35 \\
\hline & Diuron & $2.7(1.4-4.6)$ & 34.87 & $9.1(8.2-10.1)$ & 5.72 \\
\hline & Paraquat & $1.3(1.0-2.2)$ & 23.72 & $7.1(5.0-10.3)$ & 21.77 \\
\hline & Simazine & $22.7(9.5-43.0)$ & 48.28 & $80.0(55.8-98.4)$ & 14.82 \\
\hline
\end{tabular}

Table 3

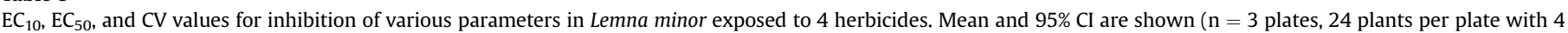
plants per concentration). (Unit: $\mu \mathrm{g} \cdot \mathrm{L}^{-1}$ ).

\begin{tabular}{|c|c|c|c|c|c|}
\hline \multirow[t]{2}{*}{ End point } & \multirow[t]{2}{*}{ Herbicides } & \multicolumn{4}{|l|}{ Lemna minor } \\
\hline & & $\mathrm{EC}_{10}(95 \% \mathrm{CI})$ & $\mathrm{CV}(\%)$ & $\mathrm{EC}_{50}(95 \% \mathrm{CI})$ & $\mathrm{CV}(\%)$ \\
\hline \multirow[t]{4}{*}{$\mathrm{RGR}_{\text {area }}$} & Atrazine & $51.0(16.1-129.2)$ & 53.51 & $219.6(175.9-300.8)$ & 12.66 \\
\hline & Diuron & $12.3(7.5-14.3)$ & 14.0 & $34.6(29.8-37.7)$ & 6.07 \\
\hline & Paraquat & $17.3(15.1-18.3)$ & 4.86 & $56.9(54.0-58.9)$ & 2.28 \\
\hline & Simazine & $51.5(17.9-90.5)$ & 41.91 & $229.1(188.5-313.9)$ & 12.40 \\
\hline \multirow[t]{4}{*}{ Root length } & Atrazine & $17.9(8.8-65.5)$ & 83.92 & $120.7(61.6-180.7)$ & 2.40 \\
\hline & Diuron & $8.0(1.9-9.5)$ & 28.80 & $25.0(20.7-29.3)$ & 9.20 \\
\hline & Paraquat & $2.0(1.5-3.1)$ & 21.03 & $10.6(8.8-12.3)$ & 9.43 \\
\hline & Simazine & $17.8(9.8-74.1)$ & 109.18 & $226.6(123.0-294.8)$ & 17.96 \\
\hline \multirow{4}{*}{$\mathrm{F}_{\mathrm{v}} / \mathrm{F}_{\mathrm{m}}$} & Atrazine & $30.6(0.2-119.0)$ & 58.73 & 341.5 & - \\
\hline & Diuron & $8.2(0-11.7)$ & 27.69 & $>50$ & - \\
\hline & Paraquat & $15.6(0.9-24.1)$ & 12.72 & $>100$ & - \\
\hline & Simazine & $37.0(24.3-54.5)$ & 22.55 & $>500$ & - \\
\hline \multirow[t]{4}{*}{$\mathrm{F}_{\mathrm{v}}^{\prime} / \mathrm{F}_{\mathrm{m}}^{\prime}$} & Atrazine & $8.9(6.2-15.8)$ & 28.51 & $57.3(30.9-76.5)$ & 17.82 \\
\hline & Diuron & $1.6(1.2-2.1)$ & 15.94 & $9.9(9.2-10.4)$ & 2.93 \\
\hline & Paraquat & $7.3(4.2-9.9)$ & 21.39 & $36.0(31.6-41.3)$ & 6.70 \\
\hline & Simazine & $10.2(8.9-12.4)$ & 9.06 & $59.8(51.5-71.3)$ & 8.30 \\
\hline \multirow[t]{4}{*}{$\mathrm{ETR}_{\max }$} & Atrazine & $8.8(5.2-35.9)$ & 101.13 & $43.3(26.2-67.3)$ & 24.33 \\
\hline & Diuron & $3.1(1.0-6.0)$ & 48.73 & $9.5(8.2-10.5)$ & 6.34 \\
\hline & Paraquat & $1.3(0.9-3.2)$ & 63.57 & $6.6(4.7-9.8)$ & 21.86 \\
\hline & Simazine & $13.6(7.7-37.4)$ & 69.41 & $59.3(47.9-75.1)$ & 11.39 \\
\hline
\end{tabular}

The effective quantum yield of PSII $\left(\mathrm{F}_{\mathrm{v}}^{\prime} / \mathrm{F}^{\prime}{ }_{\mathrm{m}}\right)$ decreased significantly with increasing herbicide concentrations $(p<0.05)$. The rank order, based on $\mathrm{EC}_{50} \mathrm{~s}$, was diuron $>$ paraquat $>$ simazine $>$ atrazine for $L$. gibba, and diuron > paraquat $>$ atrazine $>$ simazine for L. minor and L. paucicostata. CV values were between 2.93 and $17.82 \%$ for all the tested herbicides in the three Lemna species (Table 2).

Maximum electron transport rates $\left(\mathrm{ETR}_{\max }\right)$ of the plants exposed to all herbicides were significantly $(p<0.05)$ inhibited with a rank order of paraquat $>$ diuron $>$ atrazine $>$ simazine for $L$. gibba and $L$. minor, and diuron $>$ paraquat $>$ simazine $>$ atrazine for $L$. paucicostata.

3 correlative relationships between the two endpoints (effective quantum yield vs root regrowth, root regrowth vs frond area and effective quantum yield vs frond area) were summarized in Figs. 1-3.

\section{Discussion}

Atrazine, diuron, and simazine are all photosystem II (PSII) inhibitors while paraquat inhibits photosystem I (PSI). Atrazine and simazine both compete with the second electron acceptor $\left(Q_{B}\right.$ binding site) of the D1 protein in PSII, and exert a similar mode of actions whereas diuron strongly blocks the re-oxidation of the primary electron acceptor (Qa) (Ralph, 2000). These three PSII herbicides inhibit photosynthetic electron flow, leading to reduced $\mathrm{CO}_{2}$ fixation and growth in plants. Paraquat accepts electrons from $\mathrm{Fe}-\mathrm{S}$ centers and/or ferredoxin of the PSI complex which disrupts electron transfer to NADP (Eullaffroy and Vernet, 2003). Exposure to all these herbicides also generates reactive oxygen species (ROS) such as superoxide and hydroxyl radicals, and $\mathrm{H}_{2} \mathrm{O}_{2}$, which causes oxidative damage within plant cells (Dodge, 1975).

The most frequently measured endpoint in Lemna toxicity tests 
Table 4

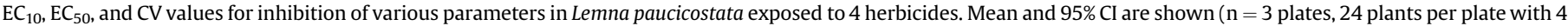
plants per concentration). (Unit: $\mu \mathrm{g} \cdot \mathrm{L}^{-1}$ ).

\begin{tabular}{|c|c|c|c|c|c|}
\hline \multirow[t]{2}{*}{ End point } & \multirow[t]{2}{*}{ Herbicides } & \multicolumn{4}{|l|}{ Lemna paucicostata } \\
\hline & & $\mathrm{EC}_{10}(95 \% \mathrm{CI})$ & $\mathrm{CV}(\%)$ & $\mathrm{EC}_{50}(95 \% \mathrm{CI})$ & $\mathrm{CV}(\%)$ \\
\hline \multirow{4}{*}{$\mathrm{RGR}_{\text {area }}$} & Atrazine & $104.1(67.2-132.4)$ & 17.70 & $342.2(277.5-373.4)$ & 7.33 \\
\hline & Diuron & $10.8(7.1-12.9)$ & 14.08 & $24.3(22.7-26.8)$ & 4.12 \\
\hline & Paraquat & $23.1(12.4-27.0)$ & 13.28 & $45.6(41.2-51.1)$ & 5.26 \\
\hline & Simazine & $43.8(32.9-59.5)$ & 15.43 & $209.8(170.8-291.0)$ & 14.82 \\
\hline \multirow[t]{4}{*}{ Root length } & Atrazine & $82.6(19.7-130.6)$ & 33.39 & $206.2(181.4-224.2)$ & 5.38 \\
\hline & Diuron & $5.9(2.7-9.5)$ & 35.09 & $20.0(19.1-21.0)$ & 2.50 \\
\hline & Paraquat & $1.3(1.2-1.6)$ & 7.81 & $7.9(5.8-11.0)$ & 18.99 \\
\hline & Simazine & $59.6(18.9-77.1)$ & 26.19 & $162.8(111.5-250.0)$ & 22.42 \\
\hline \multirow[t]{4}{*}{$\mathrm{F}_{\mathrm{v}} / \mathrm{F}_{\mathrm{m}}$} & Atrazine & $16.4(11.9-22.4)$ & 10.57 & $126.2(112.2-160.1)$ & 6.51 \\
\hline & Diuron & $1.3(0.9-2.0)$ & 12.63 & $8.3(6.0-11.0)$ & 9.58 \\
\hline & Paraquat & $14.7(8.6-20.1)$ & 12.52 & $>100$ & - \\
\hline & Simazine & $27.2(11.7-45.9)$ & 23.55 & $143.2(112.5-184.6)$ & 8.30 \\
\hline \multirow[t]{4}{*}{$\mathrm{F}_{\mathrm{v}}^{\prime} / \mathrm{F}_{\mathrm{m}}^{\prime}$} & Atrazine & $10.0(8.5-11.9)$ & 9.60 & $58.3(53.5-64.2)$ & 4.46 \\
\hline & Diuron & $1.5(1.3-1.7)$ & 6.09 & $7.8(6.8-8.6)$ & 6.06 \\
\hline & Paraquat & $7.2(4.3-9.7)$ & 18.58 & $30.1(27.5-32.5)$ & 4.62 \\
\hline & Simazine & $14.1(11.8-17.1)$ & 9.65 & $66.2(58.1-74.1)$ & 6.91 \\
\hline \multirow[t]{4}{*}{$\mathrm{ETR}_{\max }$} & Atrazine & $13.5(7.4-35.9)$ & 60.26 & $58.0(45.2-73.9)$ & 12.17 \\
\hline & Diuron & $1.5(1.1-3.2)$ & 44.72 & $7.6(5.6-9.5)$ & 14.91 \\
\hline & Paraquat & $1.6(1.1-3.1)$ & 55.72 & $8.0(5.5-9.7)$ & 14.65 \\
\hline & Simazine & $17.8(8.9-37.2)$ & 17.95 & $55.6(47.2-63.9)$ & 7.45 \\
\hline
\end{tabular}
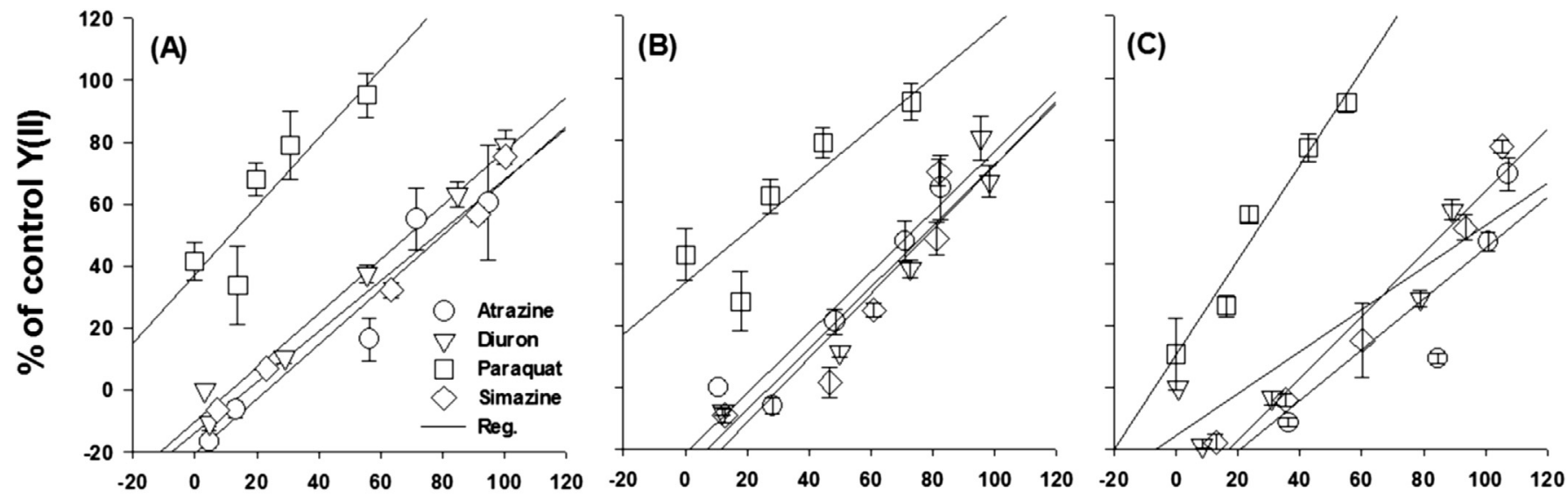

$\%$ of control root regrowth length

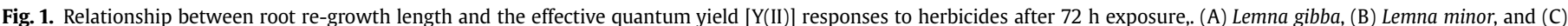
Lemna paucicostata.

is frond area. In this study, the sensitivity of frond area was compared with that of two other endpoints, but measured after 3 days of exposure instead of the typical 7 days. It is usually accepted that the longer exposure time, the greater sensitivity to toxicants (Mohammad et al., 2010) and therefore, the use of shorter exposure periods should be taken into account when interpreting the present results. Based on RGRs derived from frond area, the most toxic herbicide was diuron with $\mathrm{EC}_{50}$ values of $24.3-34.6 \mu \mathrm{g} \mathrm{L}^{-1}$ for the three Lemna species tested, which did not differ significantly in their responses. These values obtained after 3 days of exposure are similar to the reported $\mathrm{EC}_{50}$ values $\left(16.0-102.0 \mu \mathrm{g} \mathrm{L}^{-1}\right)$ for vegetative growth endpoints including frond number, frond area, fresh and dry weight in Lemna species exposed to diuron for 7 days (Table 5). Values obtained for paraquat ( $\mathrm{EC}_{50}$ S of $45.6-56.9 \mu \mathrm{g} \mathrm{L}^{-1}$ ) and simazine (209.8-276.1 $\mu \mathrm{g} \mathrm{L}^{-1}$ ) were also within previously reported ranges of the two herbicides $\left(\mathrm{EC}_{50} 17-617 \mu \mathrm{g} \mathrm{L}^{-1}\right.$, paraquat; $100-550 \mu \mathrm{g} \mathrm{L}^{-1}$, simazine); differences between species were not significant. It was notable that the toxicity of atrazine was species-specific with the ranking order of
L. gibba $>$ L. minor $>$ L. paucicostata. A literature search provided evidence for a similar toxicity ranking for the same three species (Table 5).

The relatively low CV values of the frond area endpoint (2.28-14.82\%) indicate good repeatability and stability of the method (Table 2).

Changes to the methodology of the test procedure did not alter the sensitivity to the four herbicides previously reported using conventional tests.

\subsection{Root re-growth}

In the past, little attention has been paid to the roots in Lemna since it was generally considered that root fragility made their handling for measurements difficult and that it was impractical to obtain sufficient numbers of individual plants with identical root lengths to initiate tests. However, more recently the ecotoxicological significance of the root endpoint has been re-evaluated and root length was shown to be a sensitive, precise and ecologically 

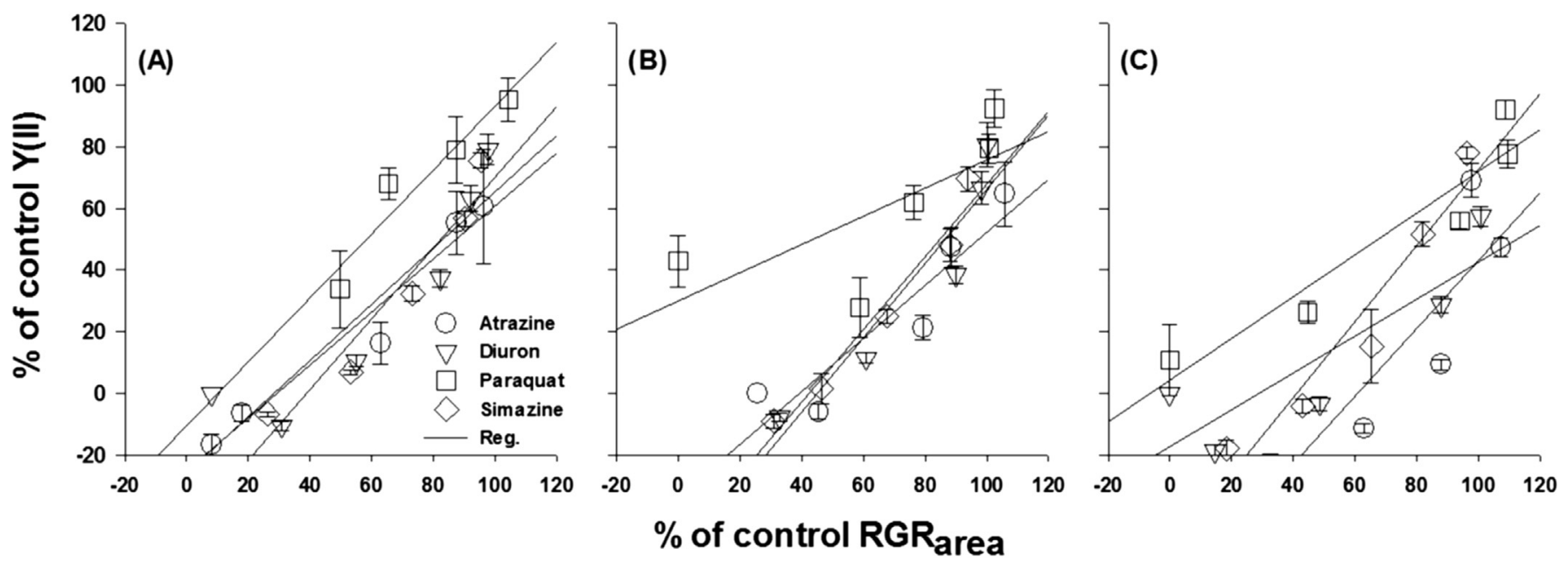

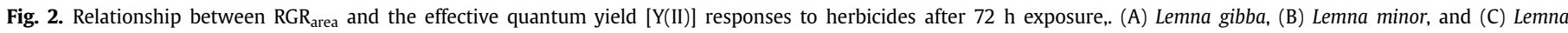
paucicostata.
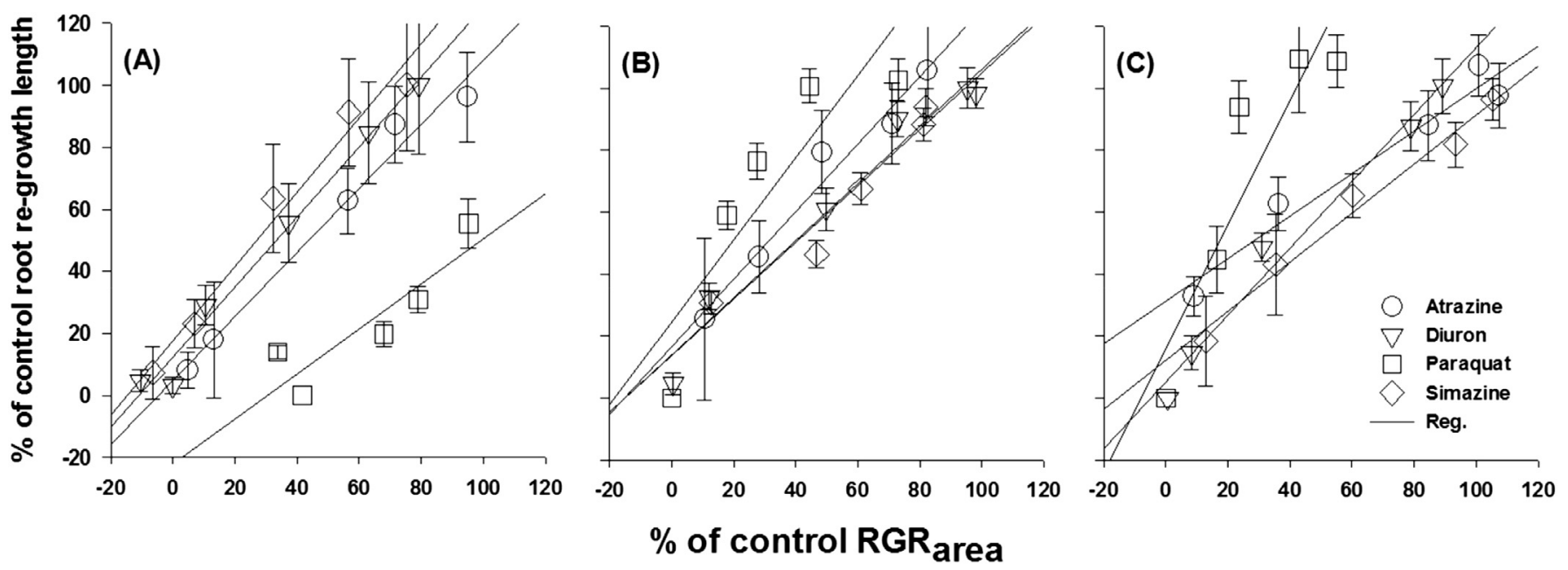

Fig. 3. Relationship between $\mathrm{RGR}_{\text {area }}$ and root re-growth length responses to herbicides after 72 h exposure,. (A) Lemna gibba, (B) Lemna minor, and (C) Lemna paucicostat.

significant endpoint in comparison with more traditional frond growth and biomass endpoints (Park et al., 2013; Gopalapillai et al., 2014).

Compared with results obtained from measurements of frond area, root re-growth showed paraquat to be the most toxic of the tested herbicides to all three Lemna species, with mean $\mathrm{EC}_{50}$ values of 7.1, 7.9 and $10.6 \mu \mathrm{g} \mathrm{L}^{-1}$ for L. gibba, L. paucicostata and L. minor, respectively. Diuron was the second most toxic herbicide to root regrowth although it was most toxic to frond growth. It is however notable that the $\mathrm{EC}_{50}$ values of diuron toxicity were similar between these two endpoints, indicating similar mechanism of diuron toxicity to vegetative growth processes. The sensitivity of root lengths to diuron $\left(\mathrm{EC}_{50}=14.8-20.0 \mu \mathrm{g} \mathrm{L}^{-1}\right)$ was similar to or higher than that of other growth endpoints $\left(\mathrm{EC}_{50}=15-450 \mu \mathrm{g} \mathrm{L}^{-1}\right.$, Table 5). The range of coefficients of variation of the root test method was between 2.4 and $22.42 \%$, which was again within the recommendable levels of variation for standard test methods (Table 2).

\subsection{Chlorophyll a fluorescence}

One of the most frequently used methods for monitoring the status of the photosynthetic apparatus in plants is in vivo chlorophyll $a$ fluorescence, a non-destructive, straightforward and rapid technique that is applicable in both laboratory and field studies. It is used as a potential indicator of exposure to environmental and chemical stresses, including herbicides.

The impact of certain herbicides, such as commonly used ones like diuron, atrazine and simazine, on the photochemical activity of PSII has long been recognized (Beaumont et al., 1976; Merlin et al., 1993; Küster and Altenburger, 2007; Kumar and Han, 2011). Such PSII inhibitors restrict photosynthetic activity through their binding to the D1 protein in thylakoids and blocking electron transport through the PSII reaction center with effects being manifested by changes in various chlorophyll fluorescence parameters (Murata et al., 2007).

The maximum quantum yield of PS II chemistry, which is provided by the ratio $F_{v} / F_{m}$ (Genty et al., 1992), is consistent across higher plants species which typically have $F_{v} / F_{m}$ maxima of about 0.84 ; this is also true for the Lemna spp. $(0.68 \pm 0.04)$ in this study. $\mathrm{F}_{\mathrm{v}} / \mathrm{F}_{\mathrm{m}}$ assesses the intrinsic photochemical efficiency of PS II, reflecting the intactness of the PS II/LHC II complex or the intactness of thylakoid membranes Björkman and Demmig 1987; DeEll et al. 1999), which may not become apparent when the site of 
Table 5

List of herbicides toxicity tests using various endpoints in Lemna sp.

\begin{tabular}{|c|c|c|c|c|c|}
\hline Toxicant & Test organism & End-point & Exposure time & $\mathrm{EC}_{50}\left(\mu \mathrm{g} \cdot \mathrm{L}^{-1}\right)$ & References \\
\hline \multirow[t]{50}{*}{ Atrazine } & \multirow[t]{2}{*}{ L. gibba } & \multirow[t]{2}{*}{ FN } & $14 d$ & 1600 & \multirow[t]{2}{*}{ Mohammad et al. (2010) } \\
\hline & & & $28 d$ & 89 & \\
\hline & \multirow[t]{4}{*}{ L. gibba } & \multirow[t]{4}{*}{ NR } & \multirow[t]{4}{*}{$14 d$} & $37(19-72)$ & \multirow[t]{4}{*}{ Hoberg (1993) } \\
\hline & & & & $50(22-80)$ & \\
\hline & & & & $22(4.8-100)$ & \\
\hline & & & & $45(15-140)$ & \\
\hline & \multirow[t]{15}{*}{ L. gibba } & FN & $3 d$ & $102(51-127)$ & Brain et al. (2012) \\
\hline & & & $5 d$ & $86(52-111)$ & \\
\hline & & & $7 d$ & $65(52-79)$ & \\
\hline & & & $9 d$ & $>77$ & \\
\hline & & & 14 & $67(62-71)$ & \\
\hline & & GR & $3 d$ & $>137$ & \\
\hline & & & $5 d$ & $>137$ & \\
\hline & & & $7 d$ & $124(90-150)$ & \\
\hline & & & $9 d$ & $>77$ & \\
\hline & & & $14 \mathrm{~d}$ & $>75$ & \\
\hline & & $\mathrm{BM}$ & $3 d$ & $90(59-110)$ & \\
\hline & & & $5 d$ & $66(56-75)$ & \\
\hline & & & $7 d$ & $57(48-67)$ & \\
\hline & & & $9 d$ & $>77$ & \\
\hline & & & $14 d$ & $64(58-68)$ & \\
\hline & L. gibba & FN & $7 d$ & $120.0(32.9-207.1)$ & Rentz (2009) \\
\hline & & PN & & $128.4(0-365.6)$ & \\
\hline & & WM & & $64.3(0-174.9)$ & \\
\hline & & $\mathrm{DM}$ & & $93.0(0-295.9)$ & \\
\hline & & RGR(FN) & & $187.9(119.2-256.7)$ & \\
\hline & & RGR(PN) & & $292.2(0-590.6)$ & \\
\hline & L. minor & FN & $7 d$ & $133.6(83.5-183.7)$ & \\
\hline & & PN & & $146.9(76.1-217.7)$ & \\
\hline & & WM & & $84.5(55.9-113.1)$ & \\
\hline & & $\mathrm{DM}$ & & $79.9(63.6-96.1)$ & \\
\hline & & RGR(FN) & & $218.2(182.1-254.3)$ & \\
\hline & & RGR(PN) & & $321.0(260.1-381.8)$ & \\
\hline & L.minor & FN & $10 \mathrm{~d}$ & 56 & Kirby and Sheahan (1994) \\
\hline & & FW & & 60 & \\
\hline & & $\mathrm{CHL}$ & & 62 & \\
\hline & L.minor & FN & $4 d$ & $153(89-217)$ & Fairchild et al. (1997) \\
\hline & L.minor & FN & $14 \mathrm{~d}$ & $92(80-104)$ & Fairchild et al. (1998) \\
\hline & L.minor & FW & $7 d$ & $121(102-136)$ & Teodorovic et al. (2011) \\
\hline & & FN & & $215(172-234)$ & \\
\hline & & FA & & $188(162-210)$ & \\
\hline & L.minor & $\Delta \mathrm{F} / \mathrm{F}_{\mathrm{m}}^{\prime}$ & $1 \mathrm{~h}$ & 323 & Küster and Altenburger (2007) \\
\hline & & & $5 \mathrm{~h}$ & 138 & \\
\hline & & & $24 \mathrm{~h}$ & 131 & \\
\hline & L. minor & Photosynthesis & $10,15,20 d$ & 1000 & Beaumont et al. (1976) \\
\hline & L.minor & NR & $7 d$ & 197.42 & Blackburn (1988) \\
\hline & & & & 86.3 & \\
\hline & L.paucicostaa & FA & $7 d$ & 929 & Michel et al. (2004) \\
\hline & L. perpusilla & RGR & $7 d$ & $13,487(16,000-32,000)$ & Phewnil et al. (2012) \\
\hline & Lemna sp. & $\mathrm{F}_{\mathrm{v}} / \mathrm{F}_{\mathrm{m}}$ & $4 d$ & $107(92-122)$ & Kumar and Han (2011) \\
\hline Diuron & L. gibba & FN & $7 d$ & $41.6(12.1-71.2)$ & Rentz (2009) \\
\hline & & PN & & $61.8(0-145.2)$ & \\
\hline & & WM & & $30.5(13.6-47.4)$ & \\
\hline & & DM & & $32.0(18.8-45.2)$ & \\
\hline & & $\mathrm{CHL}$ & & $2.3 \times 10^{5}\left(0-9.1 \times 10^{6}\right)$ & \\
\hline & & RGR(FN) & & $74.7(25.0-124.3)$ & \\
\hline & & RGR(PN) & & $115.7(0-255.4)$ & \\
\hline & L. minor & FN & $7 d$ & $54.9(22.3-87.5)$ & \\
\hline & & PN & & $51.7(24.5-78.8)$ & \\
\hline & & WM & & $44.1(15.1-73.2)$ & \\
\hline & & DM & & $41.8(12.1-71.4)$ & \\
\hline & & RGR(FN) & & $102.0(54.2-149.7)$ & \\
\hline & & RGR(PN) & & $97.7(70.8-124.6)$ & \\
\hline & L. minor & FN & $7 d$ & $25.0(22.0-28.0)$ & Teisseire et al. (1999) \\
\hline & L. perpusilla & FN & $7 d$ & 15 & Liu and Cendeno-Maldonado (1974) \\
\hline & Lemna sp. & RGR(FN) & $7 d$ & $20.0(15.0-28.0)$ & Kumar and Han (2010) \\
\hline & & RGR(FA) & & $16.0(10.0-22.0)$ & \\
\hline & & RGR(FW) & & $11.0(5.0-15.0)$ & \\
\hline & & $\mathrm{F}_{\mathrm{v}} / \mathrm{F}_{\mathrm{m}}$ & & $9.0(8.0-10.0)$ & \\
\hline & & ETRmax & & $9.0(6.0-10.0)$ & \\
\hline & Lemna sp. & NR & $1 d$ & 450 & Knauf and Schulze (1972) \\
\hline Paraquat & L. gibba & RGR & $7 d$ & 31 & Mohammad and Itoh (2011) \\
\hline & L. gibba & RGR & $14 \mathrm{~d}$ & $27.3(17-85.8)$ & U.S. EPA (2013) \\
\hline
\end{tabular}

(continued on next page) 
Table 5 (continued)

\begin{tabular}{|c|c|c|c|c|c|}
\hline Toxicant & Test organism & End-point & Exposure time & $\mathrm{EC}_{50}\left(\mu \mathrm{g} \cdot \mathrm{L}^{-1}\right)$ & References \\
\hline \multirow{13}{*}{ simazine } & L. minor & FN & $5 d$ & 107 & Tokousbalides et al. (2007) \\
\hline & L. minor & FN & $4 d$ & $51(25-77)$ & Fairchild et al. (1997) \\
\hline & L. paucicostata & FA & $7 d$ & 617 & Michel et al. (2004) \\
\hline & \multirow[t]{4}{*}{ L.gibba } & FN & $14 d$ & $310-620$ & Mazzeo et al. (1998) \\
\hline & & DW & & $260-550$ & \\
\hline & & $\mathrm{CHL}$ & & $290-530$ & \\
\hline & & SA & & $330-530$ & \\
\hline & \multirow[t]{4}{*}{ L.minor } & $\Delta \mathrm{F} / \mathrm{F}_{\mathrm{m}}^{\prime}$ & $10 \mathrm{~d}$ & $2670(2170-3290)$ & Merlin et al. (1993) \\
\hline & & FN & & $550(430-700)$ & \\
\hline & & $\Delta \mathrm{F} / \mathrm{F}_{\mathrm{m}}^{\prime}$ & $4 d$ & $>3000$ & \\
\hline & & FN & & $350(250-510)$ & \\
\hline & L. minor & FN & $7 d$ & $100-1000$ & Okamura et al. (2000) \\
\hline & L.minor & FN & $4 d$ & $166(102-230)$ & Fairchild et al. (1997) \\
\hline
\end{tabular}

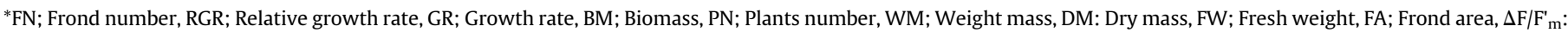
Effective quantum yield, Fv/Fm; Optimal quantum yield, ETRmax; The maximum electron transport rate, CHL; Chlorophyll, SA; Surface area, NR; Not reported

herbicide action is in another part of the plant (Murchie and Lawson, 2013). Of the four herbicides tested, only atrazine caused a significant reduction in $F_{v} / F_{m}$ within the tested concentration range $\left(6.25-500 \mu \mathrm{g} \mathrm{L}^{-1}\right)$. These results imply that the ratio of PS II/ LHC II or thylakoid membranes may have been affected by atrazine. In barley (Hordeum vulgare L. cv Boone), sub-lethal concentrations of atrazine induced the redistribution of light-harvesting Chl from Photosystem I to Photosystem II with no effect on the number of thylakoid membrane-protein complexes associated with electron transport (De la Torre and Burkey, 1992). An increase in quantum funneling may be the reason for decreased efficiency of energy transfer in the PSII/LHC complex, thereby lowering $\mathrm{F}_{\mathrm{v}} / \mathrm{F}_{\mathrm{m}}$ in Lemna exposed to higher concentrations of atrazine.

$\mathrm{EC}_{50}$ values for the inhibition of $\mathrm{F}_{\mathrm{v}} / \mathrm{F}_{\mathrm{m}}$ by atrazine were $351.0 \mu \mathrm{g} \mathrm{L}^{-1}$ for L. gibba, $237.7 \mu \mathrm{g} \mathrm{L}{ }^{-1}$ for L. minor and $126.2 \mu \mathrm{g} \mathrm{L}^{-1}$ for $L$. paucicostata which were comparable to the inhibition of biomass $\left(57.0 \mu \mathrm{g} \mathrm{L}^{-1}\right)$ and plant number $\left(292.2 \mu \mathrm{g} \mathrm{L}^{-1}\right)$ for $L$. gibba, dry weight $\left(79.9 \mu \mathrm{g} \mathrm{L}^{-1}\right)$ and plant number $\left(321.0 \mu \mathrm{g} \mathrm{L}^{-1}\right)$ for L. minor and frond area $\left(929.0 \mu \mathrm{g} \mathrm{L}^{-1}\right)$ for L. paucicostata (Tables 2, 3, and 4).

Relatively low coefficients of variation (6.51-16.67 $\mu \mathrm{g} \mathrm{L}^{-1}$ ) for the $\mathrm{EC}_{50}$ values may indicate confidence of repeatability of $\mathrm{F}_{\mathrm{v}} / \mathrm{F}_{\mathrm{m}}$ measurements.

The effective quantum yield of PSII, as measured by $\mathrm{F}_{\mathrm{v}}{ }_{\mathrm{f}} / \mathrm{F}_{\mathrm{m}}^{\prime}$, dropped significantly with increasing herbicide concentrations $(p<0.05)$ showing the first and second toxic herbicides based on $\mathrm{EC}_{50} \mathrm{~S}$ being diuron $\left(7.8-9.9 \mu \mathrm{g} \quad \mathrm{L}^{-1}\right)$ and paraquat (30.1-39.7 $\left.\mu \mathrm{g} \mathrm{L}^{-1}\right)$, respectively in all Lemna species tested.

$\mathrm{F}_{\mathrm{v}}^{\prime} / \mathrm{F}^{\prime} \mathrm{m}$ represents the ability of a phototroph to move electrons beyond PSII and is generally considered a more sensitive indicator of herbicide impact than $F_{v} / F_{m}$ (Macinnis-Ng and Ralph, 2003). The greater sensitivity of $\mathrm{F}_{\mathrm{v}}^{\prime} / \mathrm{F}^{\prime} \mathrm{m}$ is thought to relate to processes during the period of dark adaptation, a requirement before taking $F_{v} / F_{m}$ but not $\mathrm{F}_{\mathrm{v}}^{\prime} / \mathrm{F}_{\mathrm{m}}^{\prime}$ measurements, which reduce non-photochemical quenching and the pressure on the PS II reaction centers (Maxwell and Johnson, 2000). The photosynthetic endpoint $\mathrm{F}_{\mathrm{v}}^{\prime} / \mathrm{F}_{\mathrm{m}}^{\prime}$ in response to diuron and paraquat appears to be more sensitive than the frond area endpoint $\left(24.3-34.6 \mu \mathrm{g} \mathrm{L}^{-1}\right.$ for diuron and $45.6-56.9 \mu \mathrm{g} \mathrm{L}^{-1}$ for paraquat), but similar to or less sensitive than root re-growth (14.8-25 $\mu \mathrm{g} \mathrm{L}{ }^{-1}$ for diuron and 7.1-10.6 $\mu \mathrm{g} \mathrm{L}^{-1}$ for paraquat).

Acceptable $\mathrm{CV}$ values for the inhibition of $\mathrm{F}_{\mathrm{v}}^{\prime} / \mathrm{F}_{\mathrm{m}}^{\prime}$ recorded with the range between 2.93 and $17.82 \%$ for all the tested herbicides in the three Lemna species.

The rate of photosynthetic electron transport (ETR) depends on the rate of photon absorption and the efficiency of PS II (Snel et al., 1998) meaning that the efficiency of PS II electron transport describes the probability that a photochemical event will result in electron transport upon absorption of a photon by the antennae of PS II. Species-specific differences in the inhibition of maximum photosynthetic electron transport rates were observed with the most toxic herbicide being paraquat for $L$. gibba $\left(7.1 \mu \mathrm{g} \mathrm{L}^{-1}\right)$ and L. minor $\left(6.6 \mu \mathrm{g} \mathrm{L}^{-1}\right)$ and diuron for $L$. paucicostata $\left(7.6 \mu \mathrm{g} \mathrm{L}^{-1}\right)$ (Tables 2, 3, and 4). The second toxic compound for inhibition of $\operatorname{ETR}_{\max }$ was diuron for $L$. gibba $\left(9.1 \mu \mathrm{g} \mathrm{L}^{-1}\right)$ and $L$. minor $\left(9.5 \mu \mathrm{g} \mathrm{L}^{-1}\right)$, but it was paraquat for $L$. paucicostata $\left(8.0 \mu \mathrm{g} \mathrm{L}^{-1}\right)$.

After a survey on 24 references reported for herbicide toxicity to Lemna species, we found that $\mathrm{EC}_{50}$ values of diuron- and paraquatinduced inhibition of $\mathrm{ETR}_{\max }$ were lowest, indicating that the endpoints were most sensitive (Table 5).

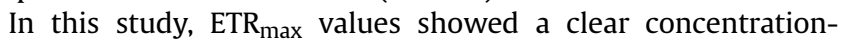
dependent decline, and their $\mathrm{EC}_{50}$ values were much lower than those of any other endpoints tested. In PAM instrumentation, calculation of ETR $\max$ based on Chl $a$ fluorescence measurement is simple and rapid, and this can be considered as the most sensitive endpoint at least for testing herbicide toxicity. The CV ranges were found to lie between 5.72 and $24.33 \%$ for all the herbicides tested with the three Lemna species.

The root re-growth bioassay also differs from three internationally standardized methods (ISO, OECD and US EPA) in that it is completed in $72 \mathrm{~h}$, the required volume of test solutions is only $3.0 \mathrm{~mL}$ and non-axenic plants are used. There are some operational advantages in being able to complete a test in 3 days, thus alleviating the need for axenic cultures. However, the sensitivity of the method is unknown when compared to the 7-d or 14-d methods. This might be a key performance characteristics and cannot be outweighed by operational advantages like speed. Tests using Lemna are most widely used for the evaluation of pesticides (especially herbicides) so a comparison of sensitivity to herbicides would await further investigations.

\section{Conclusions}

The comparative studies of the sensitivity of photosynthetic endpoints with that of growth endpoints have been made but have only shown mixed results. In this study, PAM fluorescence method was found to be more sensitive than the bioassay based on frond area inhibition. Photosynthetic electron transport events support the biochemical reactions needed for plant growth since the electron transport rate is closely related to the photosynthetic activity including oxygen evolution or $\mathrm{CO}_{2}$ uptake (Beer et al., 1998). Therefore, a direct or an indirect effect of a pollutant on photosynthetic processes is observed prior to an effect on the growth process (Juneau et al., 2003). The relationship between PSII inhibition and growth may exist for short-term studies, but detoxification of cells would be possible and recovery of growth could be 
observed, thereby the inhibition of PSII inhibition no longer reflecting the inhibition of growth (Hayat et al., 2012).

Current guidelines for the allowable concentrations in drinking waters set by Australia, Canada, New Zealand, USA, and WHO are 0.5-5 $\mu \mathrm{g} \mathrm{L}^{-1}$ for atrazine, $20-150 \mu \mathrm{g} \mathrm{L}^{-1}$ for diuron, $10 \mu \mathrm{g} \mathrm{L}^{-1}$ for paraquat and $0.5-10 \mu \mathrm{g} \mathrm{L}^{-1}$ for simazine. Sensitivity of bioassay methods is important for determination of whether to use them or not for water quality risk assessment. Effective bioassays should produce results within the relevant environmental ranges. Given that environmentally allowable concentrations of herbicides are low, this study shows that both endpoint root length and ETR $\mathrm{max}_{\operatorname{man}}$ in all three Lemna species are sensitive enough to detect toxic impacts of water samples containing diuron and paraquat in excess of allowable guidelines, and would successfully be employed for management decision. In the case of $L$. paucicostata, $\mathrm{F}_{\mathrm{v}} / \mathrm{F}_{\mathrm{m}}$ was also found to be a possible indicator of diuron toxicity at internationally allowable levels. In contrast, the Lemna bioassays would not be employed to determine whether water samples are within the environmentally allowable concentrations for atrazine and simazine. The Lemna methods show a high level of precision and reproducibility which are essential for adoption of toxicity testing methods. A desirable level of repeatability expressed by CVs is 30\% or less according to Environment Canada (2007). For all bioassays with five different endpoints $\mathrm{CV}_{\mathrm{s}}$ for $\mathrm{EC}_{50}$ values were found to lie within this acceptable range (Park et al., 2016). The present microplate method may have limitations including $\mathrm{pH}$ shifts and speciation due to small testing volume and the under estimation of some substance properties (Küster and Altenburger, 2007). However, levels of $\mathrm{EC}_{50} \mathrm{~s}$ with the microplate method using the frond area of three species of Lemna were found to be comparable to those reported for 7-day Lemna toxicity tests, suggesting that the

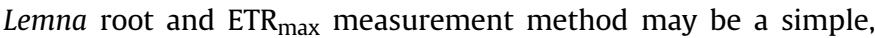
rapid, cost-effective, sensitive and precise bioassays to assess the toxic risks of herbicides in aquatic environments.

To ensure thorough evaluation of the risks posed by pollutants for environment and human health, the test methods employed should be sensitive, simple, precise and ecologically relevant (Park et al., 2012). Therefore, a technique that can assess toxicity more rapidly, simply, but without loss of sensitivity would be a valuable asset. In this respect, our 3-day frond growth test may be considered as a modified test method of 7-day standardized frond test in that testing time is important factor for determination of a bioassay since management decision should be made timely just in cases of unexpected pollution events.

\section{Acknowledgements}

This research was supported by a Grant of Incheon National University Research (2012) and partly supported by Technological Innovation R\&D Program of Co-investment between Government, Corporation and Company (Grant No. S2252500).

\section{References}

Beaumont, G., Bastin, R., Therrien, H.P., 1976. Physiological effects of sublethal doses of atrazine on Lemna minor L. i. effect on growth, chlorophyll content, proteincontent and soluble and total nitrogen. Nat. Can. 103, 535-541.

Beer, S., Vilenkin, B., Weil, A., Veste, M., Susel, L., Eshel, A., 1998. Measuring photosynthetic rates in seagrasses by pulse amplitude modulated (PAM) fluorometry. Mar. Ecol. Prog. Ser. 174, 293-300.

Björkman, O., Demmig, B., 1987. Photon yield of 02 evolution and chlorophyl fluorescence characteristics at $77 \mathrm{~K}$ among vascular plants of diverse origins. Planta 170, 489-504.

Blackburn, R.A., 1988. The Effects of Single and Joint Toxicity of Atrazine and Alachlor on Three Non-target Aquatic Organisms. University of Kansas, Lawrence p.163.

Brain, R.A., Hosmer, A.J., Desjardins, D., Kendall, T.Z., Krueger, H.O., Wall, S.B., Cedergreen, N., 2012. Recovery of duckweed from time-varying exposure to atrazine. Environ. Toxicol. Chem. 31, 1121-1128.

Christen, O., Theuer, C., 1996. Sensitivity of Lemna Bioassay interacts with stockculture period. J. Chem. Ecol. 22, 1177-1186.

De la Torre, W.R., Burkey, K.O., 1992. Physiological effects of sublethal atrazine on barley chloroplast thylakoid membranes. Photosynth. Res. 32, 1-10.

DeEll, J.R., van Kooten, O., Prange, R.K., Murr, D.P., 1999. Applications of chlorophyll fluorescence techniques in postharvest physiology. Hortic. Rev. 23, 69-107.

Dodge, A.D., 1975. Some mechanisms of herbicide action. Science Progress 62, 447-466.

Environment Canada, 2007. Guidance Document on Statistical Methods for Environmental Toxicity Tests. EC, Ottawa (ON), Canada. Report EPS 1/RM/46.

Eullaffroy, P., Vernet, G., 2003. The F684/F735 chlorophyll fluorescence ratio: a potential tool for rapid detection and determination of herbicide phytotoxicity in algae. Water Res. 37, 1983-1990.

Fairchild, J.F., Ruessler, D.S., Haverland, A.R., Carlson, A.R., 1997. Comparative sensitivity of Selenastrum capricornutum and Lemna minor to sixteen herbicides. Archives Environ. Contam. Toxicol. 32, 353-357.

Fairchild, J.F., Sappington, L.C., Ruessler, D.S., 1998. Comparative sensitivity of five species of macrophytes and six species of algae to atrazine, metribuzin, alachlor, and metolachlor. Environ. Toxicol. Chem. 17, 1830-1834.

Fatima, M., Mandiki, S.N.M., Douxfils, J., Silvestre, J., Coppe, P., Kestemont, P., 2007. Combined effects of herbicides on biomarkers reflecting immune-endocrine interactions in goldfish. Immune and antioxidant effects. Aquat. Toxicol. 81, 159-167.

Genty, B., Goulas, Y., Dimon, B., Peltier, G., Moya, I., 1992. Modulation of efficiency of primary conversion in leaves, mechanisms involved at PSII. Res. Photosynth. 4, 603-610.

Giddings, J.M., Arts, G., Hommen, U., 2012. The Relative sensitivity of macrophyte and algal species to herbicides and fungicides: an analysis using species sensitivity distributions. Integr. Environ. Assess. Manag. 9, 308-318.

Gopalapillai, Y., Vigneault, B., Hale, B.A., 2014. Root length of aquatic plant, Lemna minor L., as an optimal toxicity endpoint for biomonitoring of mining effluents. Integr. Environ. Assess. Manag. 10, 493-497.

Hayat, S., Hayat, Q., Alyemeni, M.N., Wani, A.S., Pichtel, J., Ahmad, A., 2012. Role of proline under changing environments: a review. Plant Signal. Behav. 7, 1456-1466.

Hernández, A.F., Parrón, T., Tsatsakis, A.M., Requena, M., Alarcón, R., LópezGuarnido, O., 2013. Toxic effects of pesticide mixtures at a molecular level: their relevance to human health. Toxicology 307, 136-145.

Hillman, W.S., 1961. The Lemnaceae or duckweed: a review of the descriptive and experimental literature. Bot. Rev. 27, 221-287.

Hoberg, J.R., 1993. Atrazine Technical - Toxicity to Duckweed (Lemna Gibba). SLI Report 93-4-4755. p.65.

Hulsen, K., Minne, V., Lootens, P., Vandecasteele, P., Höfte, M., 2002. A chlorophyll a fluorescence-based Lemna minor bioassay to monitor microbial degradation of nanomolar to micromolar concentrations of linuron. Environ. Microbiol. 4, 327-337.

Juneau, P., Popovic, R., 1999. Evidence for the rapid phytotoxicity and environmental stress evaluation using the PAM fluorometric method: importance and future application. Ecotoxicology 8, 449-455.

Juneau, P., Sumitomo, H., Matsui, S., Itoh, S., Kim, S.G., Popovic, R., 2003. Use of chlorophyll fluorescence of Closterium ehrenbergii and Lemna gibba for toxic effect evaluation of sewage treatment plant effluent and its hydrophobic components. Ecotoxicol. Environ. Saf. 55, 1-8.

Kirby, M.F., Sheahan, D.A., 1994. Effects of atrazine, isoproturon, and mecoprop on macrophyte Lemna minor and the alga Scenedesmus subspicatus. Environ. Contam. Toxicol. 53, 120-126.

Kloeppel, H., Koerdel, W., Stein, B., 1997. Herbicide transport by surface runoff and herbicide retention in a filter strip rainfall and runoff stimulation studies. Chemosphere 35, 129-141.

Knauf, W., Schulze, E.F., 1972. Long range effect of sublethal amounts of the herbicide linuron and monolinuron on some representative fauna and flora. Schriftenr Ver. Wasser Boden Lufthyg Berlin-Dahlem 37, 231-239.

Kumar, K.S., Han, T., 2010. Physiological response of Lemna species to herbicides and its probable use in toxicity testing. Toxicol. Environ. Health Sci. 2, 39-49.

Kumar, K.S., Han, T., 2011. Toxicity of single and combined herbicides on PSII maximum efficiency of an aquatic higher plant, Lemna sp. Toxicol. Environ. Health Sci. 3, 97-105.

Küster, A., Altenburger, R., 2007. Development and validation of a new fluorescencebased bioassay for aquatic macrophyte species. Chemosphere 67, 194-201.

Lahive, E., O'Halloran, J., Jansen, M.A.K., 2011. Differential sensitivity of four Lemnaceae species to zinc sulphate. Environ. Exp. Bot. 71, 25-33.

Liu, L.C., Cedeno-Maldonado, A., 1974. Effects of fluometuron, prometryne, ametryne, and diuron on growth of two Lemna species. Journal of Agriculture of the University of Puerto Rico 63, 483-488.

Macinnis-Ng, C.M., Ralph, P.J., 2003. Short-term response and recovery of Zostera capricorni photosynthesis after herbicide exposure. Aquat. Bot. 76, 1-15.

Marwood, C.A., Solomon, K.R., Greenberg, B.M., 2001. Chlorophyll fluorescence as a bioindicator of effects on growth in aquatic macrophytes from mixtures of polycyclic aromatic hydrocarbons. Environ. Toxicol. Chem. 20, 890-898.

Maxwell, K., Johnson, G.N., 2000. Chlorophyll fluorescence-a practical guide. J. Exp. Bot. 51, 659-668.

Mazzeo, N., Dardano, B., Marticorena, A., 1998. Interclonal variation in response to simazine stress in Lemna gibba (Lemnaceae). Ecotoxicology 7, 151-160.

Merlin, G., Eulaffroy, P., Blake, G., 1993. Use of fluorescence induction kinetics of 
Lemna minor as a tool for chemical stress evaluation. Sci. Total Environ. 134, $761-772$.

Michel, A., Johnson, R.D., Duke, S.O., Scheffler, B.E., 2004. Dose-response relationships between herbicides with different modes of action and growth of Lemna paucicostata: an improved ecotoxicological method. Environ. Toxicol. Chem. 23, 1074-1079.

Mohammad, M., Itoh, K., 2011. New concept for evaluating the toxicity of herbicides for ecological risk assessment. Agric. Biol. Sci. 561-583.

Mohammad, M., Itoh, K., Suyama, K., 2010. Effects of herbicides on Lemna gibba and recovery from damage after prolonged exposure. Archives Environ. Contam. Toxicol. 58, 605-612.

Moody, M., Miller, J., 2005. Lemna minor growth inhibition test. Small-scale Freshw. Toxic. Investig. 271-298.

Murata, N., Takahashi, S., Nishiyama, Y., Allakhverdiev, S.I., 2007. Photoinhibition of photosystem II under environmental stress. Biochimica Biophysica Acta 1767, 414-421.

Murchie, E.H., Lawson, T., 2013. Chlorophyll fluorescence analysis: a guide to good practice and understanding some new applications. J. Exp. Bot. 64, 3983-3998.

Nestler, H., Groh, K.J., Schönenberger, R., Behra, R., Schirmer, K., Eggen, R.I.L., Suter, M.J.F., 2012. Multiple-endpoint assay provides a detailed mechanistic view of responses to herbicide exposure in Chlamydomonas reinhardtii. Aquat. Toxicol. 110-111, 214-224.

Okamura, H., Aoyama, I., Takami, T., Maruyama, T., Suzuki, Y., Matsumoto, M., Katsuyama, I., Hamada, J., Beppu, T., Tanaka, O., Maguire, R.J., Liu, D., Lau, Y.L., Pacepavicius, G.J., 2000. Phytotoxicity of the new antifouling compound irgarol 1051 and a major degradation product. Mar. Pollut. Bull. 40, 754-763.

Ralph, P.J., 2000. Herbicide toxicity of Halophila ovalis assessed by chlorophyll a fluorescence. Aquat. Bot. 66, 141-152.

Park, J.S., Brown, M.T., Han, T., 2012. Phenol toxicity to the aquatic macrophyte Lemna paucicostata. Aquat. Toxicol. 106-107, 182-188.

Park, A., Kim, Y.J., Choi, E.M., Brown, M.T., Han, T., 2013. A novel bioassay using root re-growth in Lemna. Aquat. Toxicol. 140-141, 415-424.

Park, J., Jin, G.-S., Hwang, M.S., Brown, M.T., Han, T., 2016. Toxicity tests using the kelp Undaria pinnatifida for heavy metal risk assessment. Toxicol. Environ. Health Sci. 8, 86-95.

Perreault, F., Oukarroum, A., Pirastru, L., Sirois, L., Matias, W.G., Popovic, R., 2010. Evaluation of copper oxide nanoparticles toxicity using chlorophyll fluorescence imaging in Lemna gibba. J. Bot. 2010, 1-9.

Phewnil, O., Tungkananurak, N., Panichsakpatana, S., Pitiyont, B., 2012. Phytotoxicity of atrazine herbicide to fresh water macrophyte duckweed (Lemna perpusilla Torr.) in Thailand. Environ. Nat. Resour. J. 10, 16-27.

Prado, R., Rioboo, C., Herrero, C., Cid, A., 2009. The herbicide paraquat induces alterations in the elemental and biochemical composition of non-target microalgal species. Chemosphere 76, 1440-1444.

Ralph, P.J., 1997. Photoinhibitory stress Physiology of the seagrass. Halophila ovalis (R. Br.) Hook. f. Ph. D. dissertation. University of Technology, Sydney, Australia, $276 \mathrm{pp}$.

Ralph, P.J., Gademann, R., 2005. Rapid light curve: a powerful tool to assess photosynthetic activity. Aquat. Bot. 82, 222-237.

Rentz, N.C., 2009. Evaluating the Field and Laboratory Efficacy of a Toxicity Test for the Aquatic Macrophyte Elodea Canadensis. University of Manitoba, Canada p.219.

Ritchie, G., 2006. Chlorophyll fluorescence: what is it and what do the numbers mean?. In: USDA Forest Service Proceedings RMRS-p-43. US Department of Agriculture, Forest Service, Rocky Mountain Research Station, Fort Collins, CO, pp. 34-43.

Scherr, C., Simon, M., Spranger, J., Baumgartner, S., 2008. Test system stability and natural variability of a Lemna gibba L. bioassay. Plos One 3, e3133.

Schreiber, U., Quayle, P., Schmidt, S., Escher, B.I., Mueller, J.F., 2007. Methodology and evaluation of a highly sensitive algae toxicity test based on multiwell chlorophyll fluorescence imaging. Biosens. Bioelectron. 22, 2554-2563.

Snel, J.F.H., Vos, J.H., Gylstra, R., Brock, T.C.M., 1998. Inhibition of photosystem I (PSII) electron transport as a convenient endpoint to assess stress of the herbicide linuron on freshwater plants. Aquat. Ecol. 32, 113-123.

Steinberg, R.A., 1946. Mineral requirements of Lemna minor. Plant Physiol. 21, 42-48.

Teisseire, H., Couderchet, M., Vernet, G., 1999. Phytotoxicity of diuron alone and in combination with copper or folpet on duckweed (Lemna minor). Environ. Pollut. 106, 39-45.

Teodorovic, I., Knezevic, V., Tunic, T., Cucak, M., Lecic, J.N., Leovac, A., Tumbas, I.I., 2011. Myriophyllum aquaticum versus Lemna minor: sensitivity and recovery potential after exposure to atrazine. Environ. Toxicol. Chem. 31, 417-426.

Tokousbalides, M.C., Machera, K., Kyriakopoulou, K., Aliferis, K.A., Schrader, K.K. Tsoutsanis, I., Anastasiadou, P., 2007. Comparative toxicity of the phytotoxins $(8 \mathrm{R}, 16 \mathrm{R})-(-)-P y r e n o p h o r i n$ and (5S,8R ,13S,16R )-(-)-Pyrenophorol on aquatic organisms, 79. Bulletin of Environmental Contamination and Toxicology, pp. 499-503.

U.S. Environmental Protection Agency, and Office of Pesticide Programs, 2013. Pesticide Ecotoxicity Database (EEDB). Environmental Fate and Effects Division, U.S.EPA, Washington, D.C.

Wang, W., 1990. Literature review on duckweed toxicity testing. Environ. Res. 52 $7-22$.

Wang, W., Williams, J.M., 1990. The use of phytotoxicity tests (common duckweed, cabbage, and millet) for determining effluent toxicity. Environ. Monit. Assess. $14,45-58$. 